\title{
Soil nematode communities in three Natura 2000 sites of the Trascău Mountains (Romania)
}

\author{
M. Ciobanu, I. Popovici
}

Ciobanu M., Popovici I., 2015. Soil nematode communities in three Natura 2000 sites of the Trascău Mountains (Romania). Ann. For. Res. 58(2): 311-322.

Abstract. The nematode fauna in eleven localities distributed in forests and grasslands of three Natura 2000 sites (Cheile Turzii, Trascău and Cheile Turenilor) located in the Trascăului Mountains (Romania) was studied. A total of 133 nematode taxa were found, the nematode communities from the hornbeam-sessile oak forest in Cheile Turenilor being the most diverse (69 taxa), as compared to the grasslands located on sunny, steep slopes of Cheile Turzii (32-44). Only 10 taxa with higher proportions of their populations $(\mathrm{D} \geq 10.1$ ) were noted in the nematode communities. Diphtherophora brevicole, Panagrolaimus verrucosus, Trophurus sculptus, Tylencholaimellus striatus and Tylencholaimus minutus are rare records in the Romanian fauna. Dominant nematode taxa and trophic groups differed according to the ecosystems, Natura 2000 habitat types and soil depth. General opportunist nematodes prevailed in forests, whereas persisters were more abundant in calcophilous grasslands, with more mature, complex and stable nematode communities. Proportion of bacterial and fungal decomposition differed between localities, but grouping ecosystems and Natura 2000 habitat types based on the dominant decomposition pathway in soil food web was not possible. Nematode fauna of forests and grasslands was different; nematode community structure also differed in xerophilic and mesophilic grasslands. Nematode fauna is a promising ecological tool in soil-based assessment and monitoring of the conservation status of Natura 2000 habitats. Keywords Carpathians, conservation, nematode fauna, protected areas.

Authors. Marcel Ciobanu (icb@cluj.astral.ro), Iuliana Popovici - Institute of Biological Research, Branch of the National Institute of Research and Development for Biological Sciences, 48 Republicii Street, 400015 Cluj-Napoca, Romania.

Manuscript received January 09, 2015; revised March 24, 2015; accepted March 27, 2015; online first April 20, 2015.

\section{Introduction}

The Trascău Mountains are located in the southeastern part of the Apuseni Mountains, domi- nating the Mureş Valley, downstream of its confluence with the Arieş river, being a landmark of the region. The highly diverse landscape characterizing these mountains is due to lime- 
stones, which are present on large areas, with spectacular formations of exo- and endokarst (Anonymous 1987). The climate is temperate continental, with average daily temperatures ranging between $-6^{\circ} \mathrm{C}$ to $-3^{\circ} \mathrm{C}$ (January) and from 14 to $18^{\circ} \mathrm{C}$ (July). The amount of annual average precipitation reaches about $1,000 \mathrm{~mm}$ at higher altitudes, but decreases gradually to 700-800 $\mathrm{mm}$ at the eastern side of the mountains (Măhăra \& Popescu-Argeşel 1993). The orientation of mountainous edges and the presence of limestones create particular microclimatic conditions, where some interesting plant and animal species thrive, many of them being protected by the Romanian legislation. A considerable part of the area of the Trascău Mountains is currently under protection regime as several protected areas of community interest, part of the Natura 2000 European ecological network were established here, namely: Cheile Glodului, Cibului şi Măzii, Cheile Turenilor, Cheile Turzii, Trascău, Fânaţele Pietroasa Podeni and Munţii Trascăului (Anonymous 2007, Anonymous 2008, Anonymous 2011).

Traditionally, the majority of Natura 2000 sites were established taking into account vegetation, typically at the level of phyto-sociological alliances (Evans 2006), while soil biodiversity and its threats were ignored (Turbé et al. 2010). Yet, soil biota plays important roles in functioning of terrestrial ecosystems as a component of soil food web (Wardle 2002, Lavelle et al. 2006, Brussaard 2012) and including soil fauna in national strategies for conserving and sustainable use of biodiversity is a priority stipulated in the Rio Convention on Biological Diversity (1992). Plants and soil biota are tightly connected, both directly, through herbivory and symbiosis, and indirectly by the decomposition of dead organic plant material (Sylvain \& Wall 2011). Therefore, in order to protect soil biodiversity, the European Commission will increase the importance and relevance of soil in management plans for designated Natura 2000 sites (Montanarella 2008).
Free-living soil nematodes are key components of soil fauna; they are highly diversified, abundant, ubiquitous, easy to sample and trophically heterogenous. They play essential roles in ecosystems as primary and intermediate consumers, contributing to the decomposition of organic matter and are involved in the biogeochemical cycle of $\mathrm{N}$ and $\mathrm{C}$ (Coleman et al. 1984, Ingham et al. 1985, Hendrix et al. 1986, Brussaard 1994, Beare et al. 1995).

Nematode community analysis proved to be useful and relevant in assessing soil condition and anthropogenic impact, characterizing and classifying terrestrial habitats and eco-monitoring (de Goede 1993, de Goede \& Bongers 1994, Neher et al. 1995, Neher \& Campbell 1996, Urzelai et al. 2000, Popovici \& Ciobanu 2000, Ciobanu et al. 2004, De Deyn et al. 2004, Lazarova et al. 2004, Liébanas et al. 2004, Mulder et al. 2005, Lišková et al. 2008, Mincheva et al. 2009).

Previous surveys focused on the diversity and distribution of soil-dwelling nematodes in several protected areas in Romania were carried out in different parts of Romania, mainly located within the Carpathians (Popovici 1978, 1992, 1993, 1998, Popovici \& Ciobanu 1997, Ciobanu \& Popovici 1999). The results obtained were included in a complex, georeferenced database, a valuable tool with applicability in environmental management and conservation.

This study aims to characterize the structure of nematode communities in ecosystems located in protected areas within the Trascău Mountains and discuss the structural and functional diversity of nematode fauna in relation to ecosystems and Natura 2000 habitat types.

\section{Materials and methods}

The following three protected areas of community interes (also known as Natura 2000 sites) located within the Trascău Mountains were surveyed: Cheile Turzii/ROSCI0035, Trascău/ 
ROSCI0253 and Cheile Turenilor/ROSCI0034 (Fig. 1).

Eleven localities situated in deciduous forests $(n=5)$, coniferous forest $(n=1)$ and grasslands $(n=5)$ were sampled in several campaigns from 1996 until 2000, respectively (Table 1). Deciduous forests consisted of hornbeam-sessile oak $(n=3)$, hornbeam-beech $(n$ $=1)$ and black-alder $(\mathrm{n}=1)$, whereas the coniferous forest had Scots pine as dominant tree species.

The ecosystems surveyed belonged to the following seven Natura 2000 habitat types (Gafta \& Mountford 2008) (Table 1): 91Y0Dacian oak-hornbeam forests (3), 9130-Asperulo-Fagetum beech forests (1), 91E0*-Alluvial forests with Alnus glutinosa and Fraxinus excelsior (Alno-Padion, Alnion incanae, Salicion albae) (1), 91Q0-Western Carpathian calcicolous Pinus sylvestris forests (1), 6190-Rupicolous Pannonic grasslands (Stipo-Festucetalia pallentis) (3), 6240*-Sub-pannonic steppic grasslands (1) and 6520-Mountain hay meadows (1). Habitats 91E0* and 6240* are priority habitats, i.e. natural habitat types in danger of disappearance, which are present on the European territory of the member states and for the conservation of which the Community has particular responsibility (Anonymous 2007).

Nematode soil samples were collected from well-defined surfaces $\left(500 \mathrm{~m}^{2}\right)$, relevant for each habitat type. Five replicates were sampled in each site from litter and the first layer of mineral soil horizon $(0-5 \mathrm{~cm})$ in forests, separately, and the top $5 \mathrm{~cm}$ of soil in grasslands. Soil was put in plastic bags, labeled, transported at the Institute of Biological Research and stored in a cool place until processing.

Nematode extraction was carried out from $80 \mathrm{~g}$ of soil, by using the centrifugal method of De Grisse (1969), with $\mathrm{MgSO}_{4}$ as flotation agent. Nematodes were subsequently counted to estimate their abundances and killed/fixed with a $4 \%$ formaldehyde solution heated at $65^{\circ} \mathrm{C}$, to preserve a relaxed body shape.

At least 100 nematode individuals were randomly identified, using a Carl Zeiss light microscope, following Andrássy (1984) and Bongers (1988). Nematode taxa were then allocated to trophic groups (Yeates et al. 1993, Bongers \& Bongers 1998), ordered according to the colonization-persistence gradient (c-p values) (Bongers 1990, Bongers \& Bongers 1998) and assigned to functional

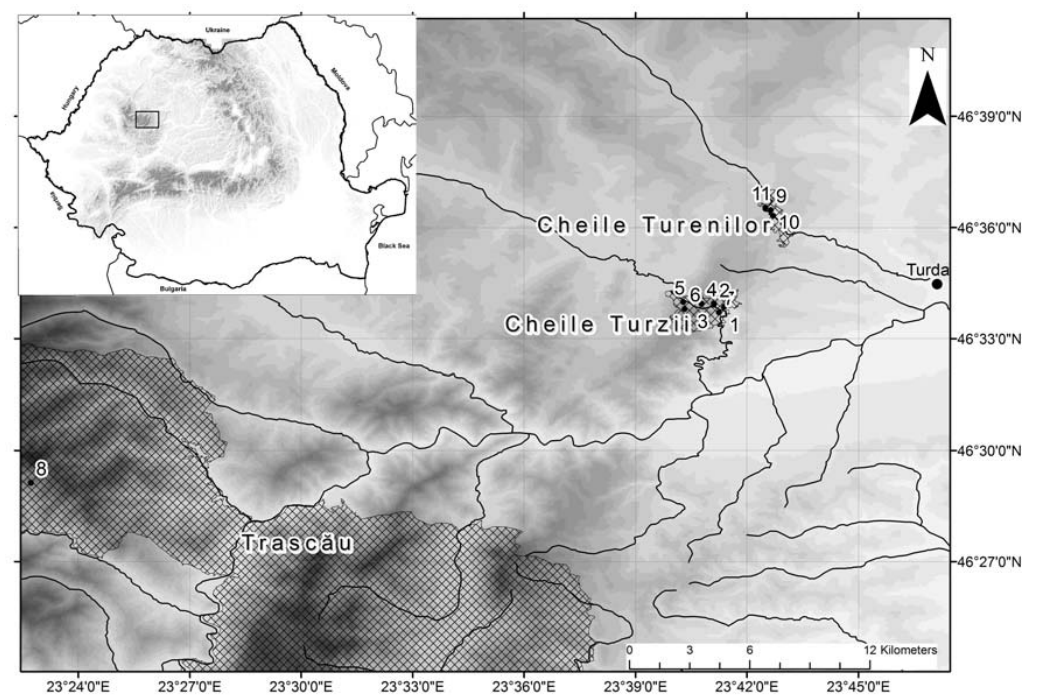

Figure 1 Sampling locations 
Table 1 Details of the sampling locations

\begin{tabular}{|c|c|c|c|c|c|}
\hline $\begin{array}{l}\text { Site } \\
\text { nr. }^{1}\end{array}$ & Natura 2000 site & Ecosystem type & $\begin{array}{l}\text { Altitude } \\
\text { (m above } \\
\text { sea level) }\end{array}$ & $\begin{array}{l}\text { Natura } 2000 \text { habitat type } \\
\text { (*-priority habitat) }\end{array}$ & Soil type \\
\hline 1 & $\begin{array}{l}\text { Cheile Turzii } \\
\text { ROSCI0035 }\end{array}$ & $\begin{array}{l}\text { Deciduous forest } \\
\text { (hornbeam-sessile oak) }\end{array}$ & 450 & $\begin{array}{l}\text { 91Y0 Dacian oak-hornbeam } \\
\text { forests }\end{array}$ & Rendzina \\
\hline 2 & $\begin{array}{l}\text { Cheile Turzii } \\
\text { ROSCI0035 }\end{array}$ & Grassland & 475 & $\begin{array}{l}6190 \text { Rupicolous Pannonic } \\
\text { grasslands }\end{array}$ & Rendzina \\
\hline 3 & $\begin{array}{l}\text { Cheile Turzii } \\
\text { ROSCI0035 }\end{array}$ & Grassland & 520 & $\begin{array}{l}6190 \text { Rupicolous Pannonic } \\
\text { grasslands }\end{array}$ & Rendzina \\
\hline 4 & $\begin{array}{l}\text { Cheile Turzii } \\
\text { ROSCI0035 }\end{array}$ & Grassland & 530 & $\begin{array}{l}\text { 6240* Sub-pannonic steppic } \\
\text { grasslands }\end{array}$ & Rendzina \\
\hline 5 & $\begin{array}{l}\text { Cheile Turzii } \\
\text { ROSCI0035 }\end{array}$ & $\begin{array}{l}\text { Deciduous forest } \\
\text { (hornbeam-sessile oak) }\end{array}$ & 505 & $\begin{array}{l}91 Y 0 \text { Dacian oak-hornbeam } \\
\text { forests }\end{array}$ & Rendzina \\
\hline 6 & $\begin{array}{l}\text { Cheile Turzii } \\
\text { ROSCI0035 }\end{array}$ & $\begin{array}{l}\text { Deciduous forest } \\
\text { (hornbeam-beech) }\end{array}$ & 430 & $\begin{array}{l}9130 \text { Asperulo-Fagetum beech } \\
\text { forests }\end{array}$ & Rendzina \\
\hline 7 & $\begin{array}{l}\text { Cheile Turzii } \\
\text { ROSCI0035 }\end{array}$ & $\begin{array}{l}\text { Coniferous forest (Scots } \\
\text { pine) }\end{array}$ & 400 & $\begin{array}{l}\text { 91Q0 Western Carpathian } \\
\text { calcicolous Pinus sylvestris } \\
\text { forests }\end{array}$ & Rendzina \\
\hline 8 & $\begin{array}{l}\text { Trascău } \\
\text { ROSCI0253 }\end{array}$ & Grassland & 675 & 6520 Mountain hay meadows & $\begin{array}{l}\text { Brown } \\
\text { luvic }\end{array}$ \\
\hline 9 & $\begin{array}{l}\text { Cheile Turenilor } \\
\text { ROSCI0034 }\end{array}$ & Grassland & 400 & $\begin{array}{l}6190 \text { Rupicolous Pannonic } \\
\text { grasslands }\end{array}$ & Rendzina \\
\hline 10 & $\begin{array}{l}\text { Cheile Turenilor } \\
\text { ROSCI0034 }\end{array}$ & $\begin{array}{l}\text { Deciduous forest } \\
\text { (hornbeam-sessile oak) }\end{array}$ & 400 & $\begin{array}{l}91 Y 0 \text { Dacian oak-hornbeam } \\
\text { forests }\end{array}$ & Rendzina \\
\hline 11 & $\begin{array}{l}\text { Cheile Turenilor } \\
\text { ROSCI0034 }\end{array}$ & $\begin{array}{l}\text { Forested waterside } \\
\text { (black alder) }\end{array}$ & 380 & $\begin{array}{l}\text { 91E0* Alluvial forests with } \\
\text { Alnus glutinosa and Fraxinus } \\
\text { excelsior }\end{array}$ & Alluvial \\
\hline
\end{tabular}

Note. ${ }^{1}$ Corespondence with sampling sites in Table 1 Supp.Info.

guilds (Bongers \& Bongers 1998, Ferris et al. 2001). BioDiversity Pro software (McAleece et al. 1997) was used to assess the diversity of nematode communities. The following indices were used for ecological characterization of nematode fauna: Maturity Index $(M I)$ for free-living nematodes and Plant Parasite Index (PPI) for herbivore nematodes (Bongers 1990), PPI/MI ratio (Bongers \& Korthals 1995) and Indices of ecosystem condition: Enrichment Index $(E I)$, Structure Index $(S I)$ and Channel Index (CI) (Ferris et al. 2001, Ferris 2010). $M I$ is an ecological measure of environmental disturbance (Bongers 1990) and an indicator of ecological succession (Bongers \& Ferris 1999), PPI shows the state of succession based on plant-feeding nematodes, being positively 314 correlated with primary production (Bongers 1990). $P P I / M I$ ratio is a sensitive indicator of nutrient status in soil (Bongers et al. 1997) and soil fertility (Bongers \& Bongers 1998). EI provides an indicator of nutrients accesible to the soil food web and the response of primary decomposers (bacteria and fungi) to them (Ferris et al. 2004), SI indicates the complexity and the degree of trophic connectance of the soil food web (Ferris et al. 2001), whereas $C I$ indicates the predominating decomposition pathway (through bacteria or fungi) in the soil food web (Ferris et al. 2001). 


\section{Results}

The analysis of nematode community structure revealed a total of 133 nematode taxa (see Table 1 from Supporting Information). There were 95 taxa present in Cheile Turzii (sites 1-7), 58 in Trascău (site 8) and 97 in Cheile Turenilor (sites 9-11). The highest diversity (69 taxa) was assessed in the hornbeam-sessile oak soil from Cheile Turenilor (site 10) as compared to the grasslands on south-oriented, steep slopes from Cheile Turzii (32 - 44 taxa) (sites 2-4 in Table 1, Supp. Info.).

The superficial rendzinas developed on limestone rocks and the high insolation, heavily affecting soil moisture, are thought to be the main limiting factors of nematode diversity in these calcophilous grasslands.

Shannon Diversity Index (Fig. 2) had little variation, the highest value (1.41) being assessed in the alluvial forest with Alnus glutinosa of Cheile Turenilor (site 11), as compared to the hornbeam-beech forest of Cheile Turzii (1.00) (site 6).

Thirty-nine taxa were present in more than half of the samples. Acrobeloides nanus, Aphelenchoides, Cephalobus, Ditylenchus, Eudorylaimus, Filenchus, Panagrolaimus rigidus and Plectus were identified in all 11 samples. The following rare species in Romanian fauna were recorded: Diphtherophora brevicole, $\mathrm{Pa}$ nagrolaimus verrucosus, Trophurus sculptus,

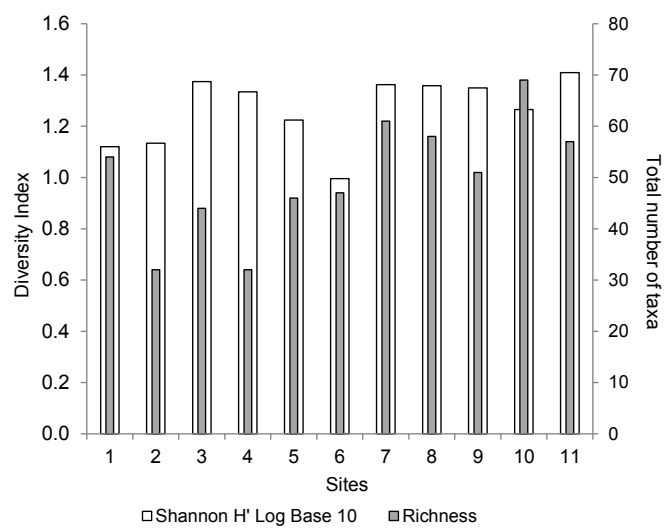

Figure 2 Shannon diversity index and richness
Tylencholaimellus striatus and Tylencholaimus minutus.

Dominant taxa ( $\mathrm{D} \geq 10.1 \%$ ) differed according to the ecosystems and Natura 2000 habitat type (codes in brackets, * - priority habitat) (Table 1, Supp. Info.): Eudorylaimus, Geocenamus, Rotylenchus robustus and Dorylaimida sensu lato had major contribution in grassland soils $(6190,6240 *, 6520)$ (sites 2, 3, 4, 8); Rhabditis, Ditylenchus and Mesocriconema rusticum prevailed in deciduous forests (91Y0, 9130, 91E0*) (sites 1, 6, 11); Aphelenchoides and Tylenchorhynchus dominated in both grasslands and deciduous forests $(6190,9130,91 \mathrm{Y} 0,91 \mathrm{E} 0 *$ ) (sites 1-3, 5, 6, 9-11), whereas Filenchus was dominant in both forest types $(9130,91 \mathrm{Q} 0,91 \mathrm{Y} 0)$ (sites 5, $6,7,10,11)$ (Table 1, Supp. Info.).

Trophic structure of nematode communities (Figures 3, 4) varied according to the ecosystems, Natura 2000 habitat type and soil depth.

Herbivore and bacterivore nematodes had major contribution to the community structure in grasslands $(6190,6520)$ (sites 3, 8 and 9 in Table 1, Supp. Info.), as well as in the alluvial forest with Alnus glutinosa (91E0*) (site 11) and calcicolous Pinus sylvestris forest (91Q0) (site 7), in this last one bacterivores surpassing numerically the herbivores.

The most balanced trophic structure was assessed in the Sub-pannonic steppic grassland $\left(6240^{*}\right)$ (site 4$)$, where bacterivores and omnivores slightly exceeded the other two groups (herbivores and fungivores) (Fig. 3).

Fungivore and bacterivore nematodes prevailed in forest litter, whereas herbivores and bacterivores dominated in the $0-5 \mathrm{~cm}$ layer of the mineral horizon (Fig. 4).

Litter favored bacterivore and fungivore nematodes, grazers of primary decomposers (microorganims and fungi) which colonize dead plant material. Higher proportions of omnivore nematodes were found in mineral soil horizon, where they represented between 6$7.8 \%$ of the whole community. Predator nematodes were very rare in litter $(<0.4 \%)$, but they 


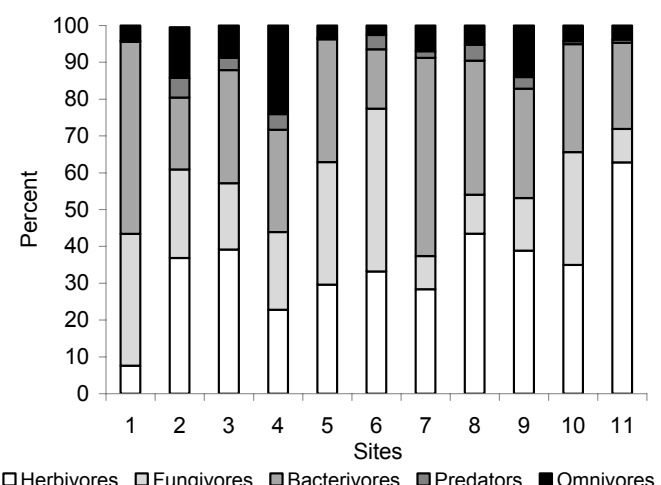

Figure 3 Trophic structure of nematode communities

proportion increased to $7.2 \%$ in mineral soil horizon.

The trophic structure of nematode communities in forest ecosystems differed according to the forest type when the whole soil profile was taken into account (Fig. 3). Hornbeam-beech forest (9130) (site 6) and hornbeam-sessile oak forest (91Y0) (site 5) were characterized by the prevalence of fungivore and herbivore nematodes, but herbivores slightly prevailed in hornbeam-sessile oak forest in site 10. The calcicolous Pinus sylvestris forest (site 7) was characterized by higher contribution of bacterivore and herbivore nematodes. These differences in the trophic structure of nematode communities according to the tree species were probably due to the quality of litter and the associated microorganisms (Scheu et al. 2003).

Interesting differences in nematode community structure were noted when trait indicators and indices of ecosystem condition and function (Bongers 1990, Bongers \& Bongers 1998, Yeates \& Bongers 1999, Ferris 2010) were derived. In general, in forest ecosystems (91Y0, 9130, 91Q0) (sites 1, 5, 6, 7, 10) prevailed c-p 2 nematodes (general opportunists), excepting the alluvial forest $(91 \mathrm{E} 0 *$ ) (site 11$)$, where c-p 3-5 nematodes (persisters) dominated the community (Fig. 5).

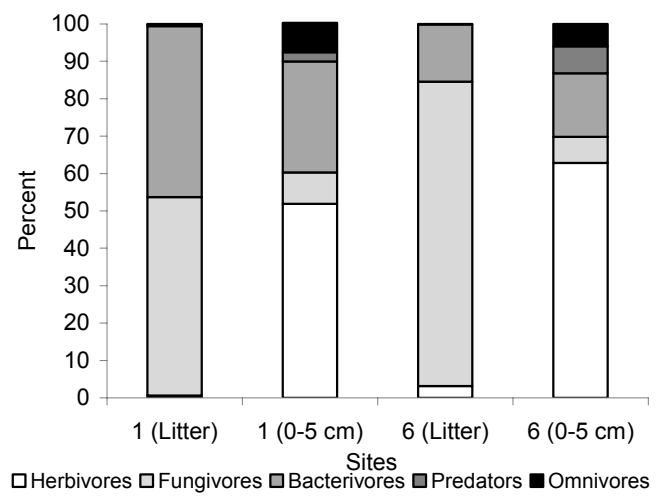

Figure 4 Trophic structure of nematode communities in organic and $0-5 \mathrm{~cm}$ layer of the mineral horizon in hornbeam-sessile oak and hornbeam-beech forests

A reverse trend was found in the rupicolous Pannonic grasslands (6190) and Sub-pannonic steppic grassland $\left(6240^{*}\right)$ (sites 2, 3, 4, 9), where persisters were preponderant, excepting the grassland in site 8 (6520), where general opportunists were more abundant (Fig. 5).

The highest values of Maturity Index for free-living nematodes indicating more mature communities (Bongers 1990) were assessed in the rupicolous Pannonic grasslands (6190) and Sub-pannonic steppic grassland $(6240 *)$ (sites $2,4,9)$, as compared to forested habitats. In these grasslands, omnivore nematodes were the most abundant (Fig. 6).

Rupicolous Pannonic grasslands (sites 2, 3, 9) and the alluvial forest (site 11) were also characterized by the highest values of Plant Parasite Index (Fig. 6), mainly due to a higher number of ectoparasitic nematodes belonging to the genus Tylenchorhynchus. The ratio between the Maturity Index and Plant Parasite Index did not show any trend whatsoever (Fig. 6).

Highest values of Enrichment Index, indicating a resource-rich environment (Ferris \& Bongers 2006) were assessed in the hornbeamsessile oak forest (91Y0) and the alluvial forest (91E0*) (sites 1 and 11), whereas the lowest were recorded in the hornbeam-beech forest 


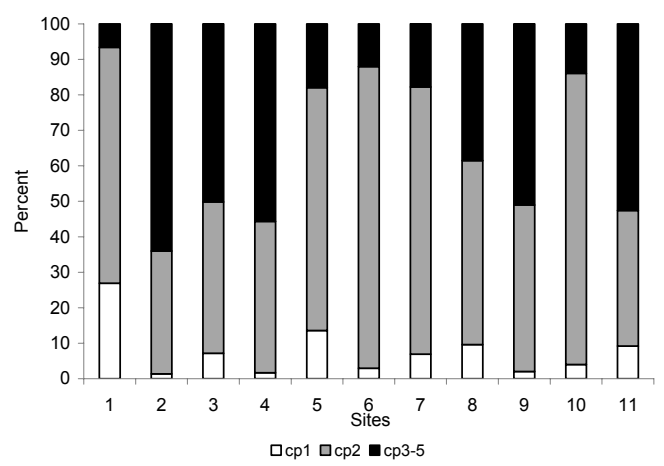

Figure 5 Structure of nematode communities based on colonizer-persister (c-p) scaling

(9130) (site 6) and the rupicolous Pannonic grassland (6190) (site 2) (Fig. 7).

The Structure Index clearly differentiated more complex nematode communities (Fig. 7). In general, rupicolous and steppic grasslands on rendzinas (sites 2, 4, 9) were better structured than hornbeam forests (sites $1,5,6,10$ ) (Fig. 7).

The Channel Index (CI) (Fig. 7), indicating the dominant decomposition channels in the soil food web, varied in different ecosystem types. The highest values of CI were found in the rupicolous Pannonic grassland (6190) (site 2) and the hornbeam-beech forest (9130) (site 6), where the lowest scores of Enrichment Index (EI) were estimated. The lowest values of CI were found in the hornbeam-sessile oak forest (91Y0) and the grassland (6520) (sites 1 and 8), where higher values of EI were also assessed. These results show that the proportion of fungal decomposition occurring at sites 2 and 6 was higher as compared to sites 1 and 8.

The Bray-Curtis Similarity Index (Fig. 8) separated nematode communities of forested and non-forested ecosystems and differentiated nematode fauna of xerophilic and mesophilic grasslands.

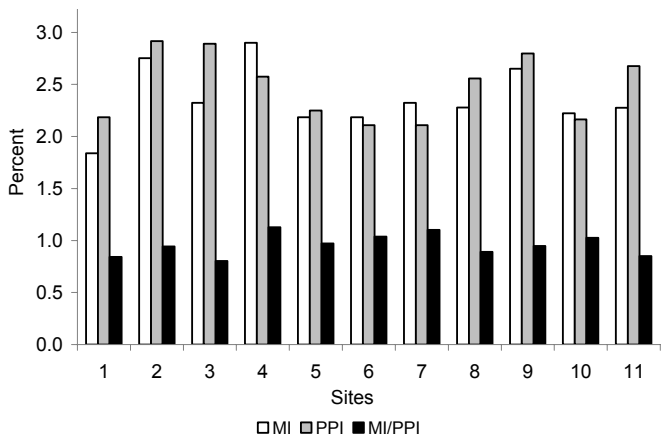

Figure 6 Maturity Index (MI) for free-living soil nematodes, Plant Parasite Index (PPI) and the ratio between MI/PPI

\section{Discussion}

Ecosystem structure and function is strongly related to environmental conditions (Moreno et al. 2011). When these conditions change, they may have significant effects on the composition of biocoenoses. Protected areas are designated to preserve biological diversity and provide a range of goods and services for people (Mulongoy \& Chape 2004). Research on the relationship between biodiversity and ecosystem services in Natura 2000 sites is surprisingly scarce (Bastian 2013), although they are primarily established for conservation purposes and provide a wide range of ecosystem services (Kettunen et al. 2009). Among soil fauna, nematodes are promising indicators of biological diversity, ecosystem stability and changes in land use management (Tomar \& Ahmad 2009). Our research showed differences regarding the structural and functional diversity of nematode fauna according to Natura 2000 habitats. Plant diversity, local climatic conditions and soil characteristics, resulting in more different, less overlapping trophic niches may explain the relatively highly diverse nematode fauna found in these Natura 2000 sites, suggesting abundant and diverse trophic resources and low competition and antagonism between taxa with similar food requirements. High di 


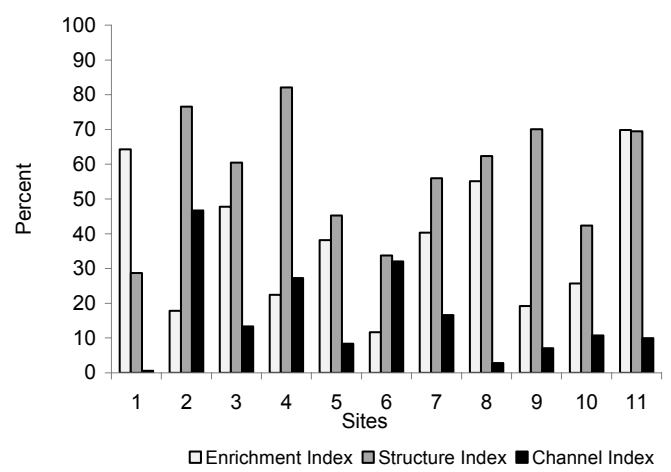

Figure 7 Enrichment Index, Structure Index and Channel Index

versity of nematode fauna in protected areas in Romania was previously reported (Popovici 1993, Popovici \& Ciobanu 1997, Ciobanu \& Popovici 1999, 2001), in line with our results.

The 133 nematode taxa found in the sites sur veyed represented about one third of the total number recorded in Romania so far (Popovici et al. 2008). Most of the taxa identified in the samples are known to be ubiquituous, with wide ecological tolerance. It is interesting to point out that several taxa were found to be eudominant $(\mathrm{D} \geq 10.1$ ) exclusively in a particular Natura 2000 habitat: dorylaimids and Geocenamus in the xero-thermophilic Rupicolous Pannonic grasslands (6190), Ditylenchus in the Asperulo-Fagetum beech forest (9130), Eudorylaimus in the meso-xerophilic Sub-pannonic steppic grassland $\left(6240^{*}\right)$ and Mesocriconema rusticum in the Alluvial forest with Alnus glutinosa and Fraxinus excelsior $(91 \mathrm{E} 0 *)$. Therefore the abundance of highertrophic level persister dorylaimids could serve as indicator of habitat stability for these two habitats.

General opportunist nematodes were more abundant in forests (91Y0, 9130, 91Q0), whereas persister nematodes were more abundant in rupicolous Pannonic grasslands (6190) and Sub-pannonic steppic grassland (6240*). General opportunists are specialized for more deliberate feeding on less available resources (Ferris \& Bongers 2006), whereas persisters 318 are more abundant in complex soil food webs of habitats with long durational stability (Bongers 1990). Higher proportion of persister nematodes in these calcophilous grasslands in Cheile Turzii, resulting also in higher values of the Maturity Index, indicates natural succession mediated by increased environmental stability (Bongers et al. 1995, Korthals et al. 1996). Highest values of Plant Parasite Index, found as well in rupicolous Pannonic grasslands suggest more favorable conditions in soil for herbivore nematodes (Lišková \& Čerevková 2005).

The Channel Index varied acccording to the ecosystem type and Natura 2000 habitat and indicated a higher proportion of bacterial decomposition occuring in the hornbeam-sessile oak forest (91Y0) and the grassland (6520) (sites 1 and 8), whereas a higher proportion of fungal decomposition was assessed in the rupicolous Pannonic grassland (6190) (site 2) and the hornbeam-beech forest (9130) (site 6). These results suggest lower $\mathrm{C} / \mathrm{N}$ ratio of organic material in sites 1 and 8 , as compared to sites 2 and 6 (Hendrix et al. 1986, Moore 1994, Ruess 2003, Ruess \& Ferris 2004, Ferris \& Bongers 2006). However, Channel Index can not be used as a reliable predictor of ecosystem type and Natura 2000 habitat, in line with previous findings (Ruess \& Ferris 2004).

The results here show that nematode community analysis offers promising perspectives in assessing soil conditions in Natura 2000 habitat types, but the use of soil nematodes as ecological tools in evaluating the conservation status of these habitats should take into account their inter-relations with abiotic and biotic factors of their environment.

\section{Conclusions}

A relatively highly diverse nematode fauna was assessed in the sites surveyed, probably as consequence of vegetation, particular microclimatic conditions and soil. Diphtherophora brevicole, Panagrolaimus verrucosus, Trophu- 


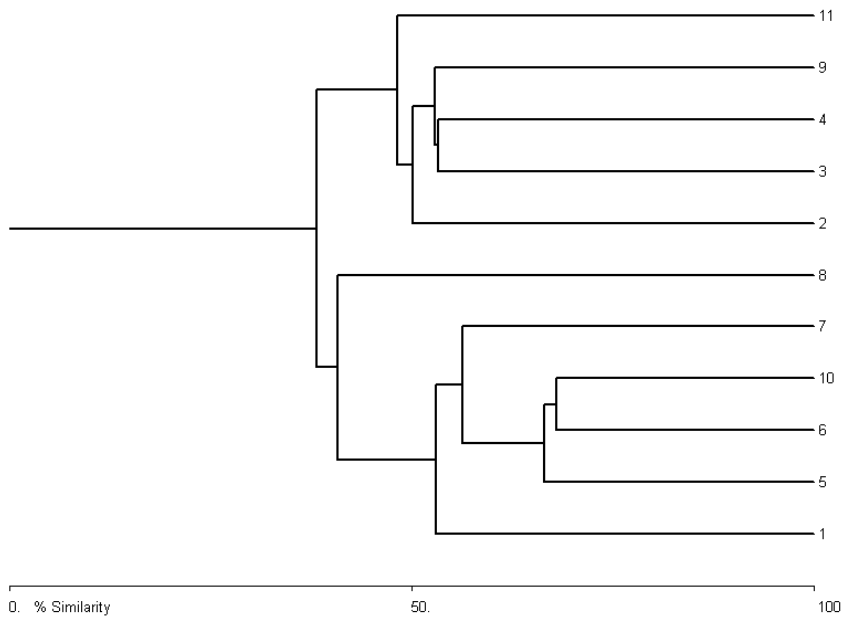

Figure 8 Bray-Curtis cluster analysis

Note. The right numbers of the dendrogram represent the corresponding site numbers, please see Table 1 .

rus sculptus, Tylencholaimellus striatus and Tylencholaimus minutus are rare nematodes in the Romanian fauna.

Specific and trophic structure of nematode communities differed according to the ecosystems, Natura 2000 habitat types and soil depth. General opportunist nematodes were more numerous in forests, whereas persisters were more abundant in calcophilous grasslands, with more complex and successionally mature nematode communities. Although proportion of bacterial and fungal decomposition differed between localities, ecosystems and Natura 2000 habitat types could not be grouped based on the predominant decomposition channel in soil food webs.

Nematode fauna offer good perspectives in assessing and monitoring the conservation status in Natura 2000 habitats.

\section{Acknowledgements}

Drs A.I. Stoica and A. Roman (Institute of Biological Research, Cluj-Napoca) are gratefully thanked for providing the map showing the sampling locations. This study was funded by the Romanian Ministry Education within the Romanian national research program PN 09$360201 / 2009$.

\section{References}

Andrássy I., 1984. Klasse Nematoda. Bestimmungsbücher zür Bodenfauna Europas [Class Nematoda. Identification books for European soil fauna], Lief 9. AkademieVerlag Berlin, 504 p.

Anonymous, 1987. Geografia României: Carpaţii Româneşti şi Depresiunea Transilvaniei [Geography of Romania]. Vol. 3. Editura Academiei Republicii Socialiste România, Bucureşti, 654 pp.

Anonymous, 2007. Ordinul nr. 776/5 mai 2007 al Ministrului Mediului şi Dezvoltării Durabile privind declararea siturilor de importanţă comunitară ca parte integrantă a reţelei ecologice europene [Order nr. 776/5 May 2007 of the Ministry of Environment and Sustainable Development for designating sites of community interest in Romania as part of the European ecological network Natura 2000]. Natura 2000 în România. Monitorul Oficial 615: 4-15.

Anonymous, 2008. Ordin nr. 1.964/13 decembrie 2007 al Ministrului Mediului şi Dezvoltării Durabile privind instituirea regimului de arie naturală protejată a siturilor de importanță comunitară, ca parte integranta a reţelei ecologice europene [Order 1.964/13 December 2007 of the Minister of Environment and Sustainable Development for establishing the natural protected area conditions of sites of community interest as part of the 
European ecological network Natura 2000 in Romania]. Natura 2000 în România, Monitorul Oficial 98: 5-16.

Anonymous, 2011. Ordinul Ministrului Mediului şi Pădurilor nr. 2.387/2011 pentru modificarea Ordinului ministrului mediului şi dezvoltării durabile nr. 1964/2007 privind instituirea regimului de arie naturală protejată a siturilor de importanţă comunitară, ca parte integrantă a rețelei ecologice europene [Order of the Minister of Environment and Forests Nr. 2.387/2011 for changing the Order of the Minister of Environment and Sustainable Development Nr. 1964/2007 for establishing the natural protected area conditions of sites of community interest as part of the European ecological network Natura 2000 in Romania]. Natura 2000 în România, Monitorul Oficial 179: 1-100.

Bastian O., 2013. The role of biodiversity in supporting ecosystem services in Natura 2000 sites. Ecological Indicators 24: 12-22. DOI: 10.1016/j.ecolind.2012.05.016.

Beare M.H., Coleman D.C., Crossley Jr D.A., Hendrix P.F., Odum E.P., 1995. A hierarchical approach to evaluating the significance of soil biodiversity to biogeochemical cycling. In: Collins H.P., Robertson G.P., Klug M.J., (eds). The significance and regulation of soil biodiversity. Springer, pp. 5-22. DOI: 10.1007/978-94011-0479-1_1.

Bongers T., Bongers M., 1998. Functional diversity of nematodes. Applied Soil Ecology 10: 239-251. DOI: 10.1016/S0929-1393(98)00123-1.

Bongers T., 1988. De Nematoden van Nederland [The nematodes of The Netherlands]. Natuurhistorische Bibliotheek van de, KNNV, nr. 46 Pirola, Schoorl, 408 p.

Bongers T., 1990. The maturity index: an ecological measure of environmental disturbance based on nematode species composition. Oecologia 83: 14-19. DOI: 10.1007/BF00324627.

Bongers T., de Goede R.G.M., Korthals G., Yeates G.W., 1995. Proposed changes of c-p classification for nematodes. Russian Journal of Nematology 3: 61-62.

Bongers T., Ferris, H., 1999. Nematode community structure as a bioindicator in environmental monitoring. Trends in Ecology and Evolution 14: 224-228. DOI: 10.1016/S0169-5347(98)01583-3.

Bongers T., Korthals G., 1995. The behaviour of MI and PPI under enriched conditions. Nematologica 41: 286.

Bongers T., van der Meulen H., Korthals G., 1997. Inverse relationship between the nematode maturity index and plant parasite index under enriched conditions. Applied Soil Ecology 6: 195-199. DOI: 10.1016/S09291393(96)00136-9.

Brussaard L., 1994. Interrelationships between biological activities, soil properties and soil management. In: Greenland D.J., Szabolcs I. (eds). Soil resilience and sustainable land use. CAB International, Wallingford, pp. 309-329.

Brussaard L., 2012. Ecosystem services provided by the soil biota. In: Wall D.H., Bardgett R.D. Behan-Pelletier V., Herrick J.E., Jones T.H., Ritz K., Six J., Strong D.R., van der Putten W.H. (eds)., Soil ecology and ecosystem services. Oxford University Press, pp. 45-58.

Ciobanu M., Popovici I., 1999. Diversity of soil nematode communities from the Suatu Natural Reserve. Studia Universitatis Babeş-Bolyai, Biologia 44: 45-51.

Ciobanu M., Popovici I., van Dobben, H.F., 2004. Patterns of relationships between nematode communities and vegetation from some salt-affected areas in Transylvania (Romania). Nematologia Mediterranea 32: 137-146.

Ciobanu M., Popovici I., 2001. Soil nematode fauna from the upper part basin of the Someşul Cald river. Lucrările celei de-a XVI Conferinţe Naţionale pentru Ştiinţa Solului, Suceava 30B: 80-86.

Coleman D.C., Anderson R.V., Cole C.V., Mc Clellan J.F., Woods L.E., Trofymow J.A., Elliott E.T., 1984. Roles of protozoa and nematodes in nutrient cycling. In: Todd, R.L. (ed.). Soil biology, American Society for Agronomy, Madison, pp. 17-28.

Convention on Biological Diversity, 1992. Web: www. cbd.int/convention/text/default.shtml. Accessed 26 November 2014.

de Deyn G.B., Raaijmakers C.E., Van der Putten W.H., 2004. Plant community development is affected by nutrients and soil biota. Journal of Ecology 92: 824-834. DOI: $10.1111 /$ j.0022-0477.2004.00924.x.

de Goede R.G.M., 1993. Terrestrial nematodes in a changing environment, $\mathrm{PhD}$ Thesis, Landbouwuniversiteit te Wageningen, $138 \mathrm{pp}$.

de Goede R.G.M., Bongers T., 1994. Nematode community structure in relation to soil and vegetation characteristics. Applied Soil Ecology 1: 29-44. DOI: 10.1016/0929-1393(94)90021-3.

de Grisse A.T., 1969. Redescription ou modification de quelques techniques utilisées dans l'etude des nematodes phytoparasitaires [Redescription or modification of some techniques used in the study of plant parasitic nematodes]. Mededelingen Rijksfakulteit Landbouwwetenschappen Gent 34: 351-370.

Evans D., 2006. The habitats of the European Union habitats directive. Biology and Environment: Proceedings of the Royal Irish Academy 106: 167-173. DOI: 10.3318/ BIOE.2006.106.3.167.

Ferris H., Bongers T., 2006. Nematode indicators of organic enrichment. Journal of Nematology 38: 3-12.

Ferris H., 2010. Form and function: metabolic footprints of nematodes in the soil food web. European Journal of Soil Biology 46: 97-104. DOI: 10.1016/ j.ejsobi.2010.01.003.

Ferris H., Bongers T., De Goede R.G.M., 2001. A framework for soil food web diagnostics: extension of the nematode faunal analysis concept. Applied Soil Ecology 18: 13-29. DOI: 10.1016/S0929-1393(01)00152-4.

Ferris H., Venette R.C., Scow K.M., 2004. Soil management to enhance bacterivore and fungivore nematode populations and their nitrogen mineralisation function. Applied Soil Ecology 25: 19-35. DOI: 10.1016/ j.apsoil.2003.07.001.

Gafta D., Mountford J.O., 2008. Manual de interpretare a 
habitatelor Natura 2000 din România [Manual for interpreting Natura 2000 Habitats from Romania]. Editura Risoprint, Cluj-Napoca, 101 p.

Hendrix P.F., Parmelee R.W., Crossley D.A., Coleman D.C., Odum E.P., Groffman P.M., 1986. Detritus food webs in conventional and no-tillage agroecosystems. Bioscience 6: 374-380. DOI: 10.2307/1310259.

Ingham R.E., Trofymow J.A., Ingham E.R., Coleman D.C. 1985. Interactions of bacteria, fungi and their nematode grazers: Effects on nutrient cycling and plant growth. Ecological Monographs 55: 119-140. DOI: 10.2307/1942528.

Kettunen M., Bassi S., Gantioler S., ten Brink P., 2009. Assessing socio-economic benefits of Natura 2000 - a Toolkit for Practitioners. Output of the European Commission project Financing Natura 2000: Cost Estimate and Benefits of Natura 2000. Institute for European Environmental Policy (IEEP), Brussels, $191 \mathrm{p}$.

Korthals G.W., de Goede R.G.M., Kammenga J.E., Bongers T., 1996. The maturity index as an instrument for risk assessment of soil pollution. In: van Straalen N.M., Krivolutski D.A., (eds.). Bioindicator Systems for Soil Pollution. Kluwer Academic, Dordecht, pp. 85-93.

Lavelle P., Decaëns T., Aubert M., Barot S., Blouin M., Bureau F., Margerie P, Mora P., Rossi J.P., 2006. Soil invertebrates and ecosystem services. European Journal of Soil Biology 42: S3-S15. DOI: 10.1016/ j.ejsobi.2006.10.002.

Lazarova S.S., de Goede R.G.M., Peneva V.K., Bongers T., 2004. Spatial patterns of variation in the composition and structure of nematode communities in relation to different microhabitats: a case study of Quercus dalechampii Ten. forest. Soil Biology and Biochemistry 36: 701-712. DOI: 10.1016/j.soilbio.2004.01.005.

Liébanas G., Guerrero P., Martín-García J.M., Pe-a-Santiago R., 2004. Spatial distribution of dorylaimid and mononchid nematodes from the southeast Iberian Peninsula: Environmental characterization of chorotypes. Journal of Nematology 36: 114-122.

Lišková M., Čerevková A., 2005. Nematode communities of river banks and adjacent meadows in the Slovak Republic. Helminthologia 42: 223-232.

Lišková M., Čerevková A., Háněl L., 2008. Nematode communities of forest ecosystems in association with various soil orders. Russian Journal of Nematology 16: 129-142.

Măhăra G., Popescu-Argeşel I., 1993. Munţii Trascău. Ghid turistic, Editura Imprimeriei Universităţii de Vest, Oradea, $144 \mathrm{p}$.

McAleece N., Gage J.D.G., Lambshead P.J.D., Paterson G.L.J., 1997. BioDiversity Professional statistics analysis software. Scottish Association for Marine Science and Natural History Museum London, http://www. sams.ac.uk/peter-lamont/biodiversity-pro.

Mincheva Y., Lazarova S., Peneva V., 2009. Nematode assemblages from Mountain Pine (Pinus mugo Turra) communities in Pirin Mountain, Bulgaria. Helmintholo- gia 46: 49-58. DOI: 10.2478/s11687-009-0010-2.

Montanarella L., 2008. Towards protecting soil biodiversity in Europe: The EU thematic strategy for soil protection. Biodiversity 9: 75-77. DOI: $10.1080 / 14888386.20$ 08.9712889 .

Moore J.C., 1994. Impact of agricultural practices on soil food web structure: Theory and application. Agriculture, Ecosystems \& Environment 51: 239-247. DOI: 10.1016/0167-8809(94)90047-7.

Moreno M., Semprucci F., Vezzulli L., Balsamo M., Fabiano M., Albertelli G., 2011. The use of nematodes in assessing ecological quality status in the Mediterranean coastal ecosystems. Ecological Indicators 11:328-336. DOI: $10.1016 /$ j.ecolind.2010.05.011.

Mulder C., Schouten A.J., Hund-Rinke K., Breure A.M., 2005. The use of nematodes in ecological soil classification and assessment concepts. Ecotoxicology and Environmental Safety 62: 278-289. DOI: 10.1016/ j.ecoenv.2005.03.028.

Mulongoy K.J, Chape S., 2004. Protected areas and biodiversity: an overview of key issues. Secretariat of the convention on biological diversity and UNEP-WCMC. Biodiversity series no. 21. UNEP-World Conservation Monitoring Centre, Cambridge, $52 \mathrm{p}$.

Neher D.A., Campbell C.L., 1996. Sampling for regional monitoring of nematode communities in agricultural soils. Journal of Nematology 28: 196-208.

Neher D.A., Peck S.L., Rawlings J.O., Campbell C.L., 1995. Measures of nematode community structure for an agroecosystem monitoring program and sources of variability among and within agricultural fields. Plant and Soil 170: 167-181. DOI: 10.1007/BF02183065.

Popovici I., 1978. Contribuţii la studiul nematodelor din rezervaţia de la Lucina (Jud. Suceava) [Contributions to the study of nematodes in the Lucina reserve (Jud. Suceava)]. Studii şi Comunicări, Ocrotirea Naturii, Suceava 4: 69-78.

Popovici I., 1992. Diversitatea nematofaunei din Delta Dunării [Diversity of nematode fauna in the Danube Delta]. Analele Ştiinţifice ale Institutului "Delta Dunării” I: 57-62.

Popovici I., 1993. Structura şi dinamica comunităţilor de nematode [Structure and dynamics of nematode communities]. In: Popovici I., (ed.). Parcul naţional Retezat- Studii ecologice. Editura West Side, Braşov, pp. 200-214.

Popovici I., 1998. Structure of nematode communities in mountain grasslands from Romania. In: De Goede R.G.M., Bongers T., (eds.). Nematode communities of northern temperate grassland ecosystems. Focus Verlag, Giessen, pp. 221-240.

Popovici I., Ciobanu M., 1997. Nematode diversity of vegetated cliffs of the Romanian Carpathians. In: Toth E., Horvath R., (eds.). Proceedings of the "Research, Conservation, Management" Conference, Aggtelek National Park Directorate, Aggtelek, vol. I, pp. 447- 459.

Popovici I., Ciobanu M., 2000. Diversity and distribution of nematode communities in grasslands from Romania 
in relation to vegetation and soil characteristics. Applied Soil Ecology 14: 27-36. DOI: 10.1016/S09291393(99)00048-7

Popovici I., Ciobanu M., Pena-Santiago R., 2008. Soil and freshwater nematodes (Nematoda) from Romania: A compendium. Collection "Monographic Papers on Nematology", 4. Servicio de Publicaciones, Universidad de Jaén, Jaén, 142 p.

Ruess L., 2003. Nematode soil faunal analysis of decomposition pathways in different ecosystems. Nematology 5: 179-181. DOI: 10.1163/156854103767139662

Ruess L., Ferris H., 2004. Decomposition pathways and successional changes. In: Cook R.C., Hunt D.J. (eds.). Proceedings of the $4^{\text {th }}$ International Congress of Nematology. Nematology Monographs and Perspectives 2. E.J. Brill, Leiden, pp. 1-10.

Scheu S., Albers D., Alphei J., Buryn R., Klages U., Migge S., Platner C., Salamon J.-A., 2003. The soil fauna community in pure and mixed stands of beech and spruce of different age: trophic structure and structuring forces. Oikos 101: 225-238. DOI: 10.1034/j.16000706.2003.12131.x.

Sylvain Z.A., Wall D.H., 2011. Linking soil biodiversity and vegetation: implications for a changing planet. American Journal of Botany 98: 517-527. DOI: 10.3732/ajb. 1000305 .

Tomar V.V.S, Ahmad W., 2009. Food web diagnostics and functional diversity of soil inhabiting nematodes in a natural woodland. Helminthologia 46: 183-189. DOI: 10.2478/s11687-009-0034-7.

Turbé A., De Toni A., Benito P., Lavelle P., Lavelle P.,
Camacho N. R., Van Der Putten W.H., Labouze E., Mudgal S., 2010. Soil biodiversity: functions, threats and tools for policy makers. Bio Intelligence Service, IRD and NIOO. Report for European Commission. DG Environment, Europe, 250 p.

Urzelai A., Hernández A.J., Pastor J., 2000. Biotic indices based on soil nematode communities for assessing soil quality in terrestrial ecosystems. Science of the Total Environment 247: 253-261. DOI: 10.1016/S00489697(99)00494-5.

Wardle D.A., 2002. Communities and ecosystems: linking the aboveground and belowground components. Vol. 34. Princeton University Press, Princeton, $480 \mathrm{p}$.

Yeates G. W., Bongers T., 1999. Nematode diversity in agroecosystems. Agriculture, Ecosystems \& Environment 74: 113-135. DOI: 10.1016/S0167-8809(99)00033-X.

Yeates G.W., Bongers T., De Goede R.G.M., Freckman D.W., Georgieva S.S., 1993. Feeding habits in soil nematode families and genera-An outline for soil ecologists. Journal of Nematology 25: 315-331.

\section{Supporting Information}

The online version of the article includes Supporting Information.

Supp. Info.: Structure (\%) of nematode communities 